\title{
The Cosmopolitan and Entrepreneurial City: Urban Reimagination in Gaziantep
}

\section{Kozmopolit ve Girişimci Kent Kimlikeri üzerinden Gaziantep’in Yeniden Tasavvuru}

Meltem KARADAĞ $\breve{G}^{*}$

Şenay LEYLA KUZU**

\begin{abstract}
Old urban center restoration and a new wave of museum-centered city life recently have emerged as a salient phenomenon in the daily lives of city dwellers in Gaziantep, Southeast Turkey. This article examines the cultural production of an urban identity here that is both cosmopolitan and entrepreneurial in nature. Drawing on contemporary theoretical work and the case of Gaziantep, this article analyzes the cosmopolitan and entrepreneurial city genre and identifies new forms of inequalities which may consequently emerge.
\end{abstract}

Keywords: Cosmopolitan city, Cosmopolitan identity, Entrepreneur city, Migration, Turkey

$\ddot{O} z$

Bu makalede Gaziantep’te kent kimliğinin kültürel üretimi üzerinde durulacaktır. Son yıllarda kentte eski kent merkezi restore edilirken yeni bir müze merkezli şehir hayatı kent sakinlerinin günlük yaşamlarında göze çarpan bir fenomen olarak ortaya çıkmaktadır. Bu makalede, kozmopolit ve girişimci kent kavramları ve bu olgunun ayrıştırıcı potansiyeli üzerinde durulacaktır. Yakın dönemde öne çıkan kozmopolit ve girişimci kente ilişkin kuramsal çalışmalardan yola çıkarak, kozmopolit ve girişimci kent janrın özellikleri ve kentteki yeni eşitsizlik biçimleri incelenecektir.

Anahtar Kelimeler: Kozmopolitan kent, Kozmopolit kimlik, Girişimci kent, Göç, Türkiye

\section{The City}

During the early period of the Republic in Turkey, the local economy was based on agriculture, and most of the population lived in rural areas. Likewise, the urban population of Gaziantep was also engaged in agriculture. Gradually, however, urban employment in agriculture declined. By 1950, agriculture had lost its importance in the urban economy, while the trade, service, and industry sectors rapidly expanded. As the number of people employed in agriculture in Gaziantep decreased in 2000, the proportion of the working population in the industry increased to $21.3 \%$. This was above the $13.3 \%$ rate in 2007 in Turkey (Turkish Statistical Institute Regional Indicators, 2007, p.406). According to a 2010 study by the Turkish Statistical Institute, $24.4 \%$ of individuals employed in Gaziantep, Adiyaman, and Kilis belonged to the agriculture sector. This rate was $25.2 \%$ in 2010 in Turkey (Turkish Statistical Institute Regional Indicators, 2010, p.76).

During the 1950s and 1960s, the city center of Gaziantep began to receive migrants from neighboring cities (Maraş, Şanlıurfa, and Adıyaman) in noticeable yet small numbers. In 1965 , almost $8 \%$ of the population was born outside of Gaziantep. Still, this percentage is rather low when compared to other provinces in Anatolia during that time, such as Kayseri, with a rate of $18 \%$; Konya, with a rate of $15 \%$; and Eskişehir, with a rate of $46 \%$. This rather slow trend persisted until the 1990s (Yüksel, 2013:194), when the second phase of migration in the city took place, involving migrants from Eastern provinces. According to the Population Movements in the Southeastern Anatolia Project, the highest population movements occurred in Gaziantep (Akşit \& Akçay, 1999, p.326). Later, between 2007 and 2008 , the population increased by $32.9 \%$, and in 2017 it had increased again by $15.7 \%$ (Turkish Statistical Institute). Simultaneously in Gaziantep, there was a transformation in the field of education. In 1975, the ratio of highly educated people was 0.80 , but in 2000 it had

\footnotetext{
* Doç. Dr. Gaziantep Üniversitesi, Fen-Edebiyat Fakültesi Sosyoloji Bölümü, mkaradag@gantep.edu.tr.

** Dr. Öğr. Üyesi. Gaziantep Üniversitesi, Fen-Edebiyat Fakültesi Sosyoloji Bölümü, leyla@gantep.edu.tr.
} 
increased to 4.79. This change was reflected in the city's class structure, within which there was an increase in the number of white-collar individuals (Statistical Institute, 2002, p.47, 52).

As the importance of agriculture in Gaziantep's urban economy has decreased while the population has increased, the city has adopted an entrepreneurial identity. Local municipalities have planned and executed strategies to sustain the city as an economic hub of enterprises in the region, and businessmen, who are among the local actors, have promoted an entrepreneurial image of the city. Accordingly, Gaziantep has been attracting more entrepreneurs and investors since the 1990s, when many entrepreneurs in the southeastern Anatolia region migrated to Gaziantep with the dream of enlarging their businesses and joining the city economy (Yüksel, 2011, p.381, 390). In fact, the city attracts both internal and transnational migrants as it has become incorporated into national as well as global markets. In recent years, small yet increasing numbers of transnational migrant workers have come to Gaziantep, generally to provide care and household services. Moreover, since March 2011, Syrian refugees steadily have flowed into the city. According to the Ministry of Interior Directorate General of Migration Management, 375,633 Syrians in Gaziantep are under temporary protection, and $18.75 \%$ of the urban population consists of Syrians. In fact, Gaziantep hosts the third largest population of Syrians among all cities in Turkey (Directorate General of Migration Management, 2018).

Finally, regarding the increasing amount of business activity in Gaziantep, local municipalities and business circles frequently have described the city as "a model of industrialization" and referred to its "entrepreneurial spirit." Moreover, the city's entrepreneurial identity may also be described as being ontological in nature. This means that it is socially constructed by entities such as municipalities, businessmen, and chambers within their discourse as they continually seek to justify the claim that Gaziantep is, in fact, an entrepreneurial community.

\section{Cosmopolitan and entrepreneurial city}

In recent studies, cosmopolitanism has often been considered as an attitude and discussed in relation to elite cosmopolitanism. It has been argued that due to their occupations, upper-middle class individuals are more mobile; thus, they are able to appreciate varied lifestyles (Lamont \& Aksartova, 2002, p.1-2). Therefore, elite cosmopolitanism indicates how openness to diversity and mobility is only open to those who enjoy advantages offered by globalization (Coulangeon, 2017, p.15). Another researcher has conceptualized cosmopolitanism as a form of moral commitment to a world community and, thus, placed it in stark contrast with nationalism (Lamont \& Aksatova 2002, p. 2). As Skrbis and Woodward (2007, p.731) have stated in reference to Beck, cosmopolitan culture is a form of social action and imagination that is globally open, fluid, and hybrid rather than local, regional or national.

Turkey's class structure significantly changed over the second half of the twentieth century. Moreover, in recent years, the service sector has grown at the expense of agriculture, as the urban population has increased from $28.7 \%$ to $62.7 \%$ and agricultural production has decreased from $46.5 \%$ to $26.5 \%$ (Karademir Hazır, 2013, p.7). This increase in the service sector has also meant that middle class lifestyles have become widespread. The highly educated middle class in Turkey are characterized by their urban and globalized taste as well as their participation preferences (Rankin, Ergin and Gökşen, 2013, p.13). While this cosmopolitan taste has been emphasized as a feature of Turkey's new globalized middle class, it has also been argued that this feature of Turkey's middle class reflects horizontal tensions. For example, Karademir has specified two cleavages within the middle class: "cultural excluders" with upper-middle class backgrounds, and "intellectuals" who lack upper-middle 
class backgrounds (Karademir Hazir, 2013, p.10-14). In addition, a recently published empirical study has distinguished another cleavage within the middle class - the "engaged provincialists." These individuals, who possess a medium income and education level, take a critical stance toward cosmopolitan taste and emerging cultural diversity, as they prefer more established and local taste ${ }^{1}$ (Rankin, Ergin, and Gökşen, 2013, p.13).

What Beck characterizes as cosmopolitan culture has also become a new cultural genre that is typical of contemporary cities. In such cities, urban renewal and reconversion projects have proliferated the cosmopolitan genre through cultural production. Indeed, contemporary cities often possess a multicultural character and transnational networks. Taking a geographical and contextual stance, Brenda S. A. Yeoh and Weiqiang Lin (2012, p.212) have highlighted asymmetrical forms of cosmopolitanism in everyday urban reality. They have argued that while cities presently market themselves as multicultural, neoliberal practices in urban planning today are accompanied by the commodification of urban space. Today's cities are not neutral spaces co-inhabited equally by individuals. Rather, "they support, through processes of subject- and place-making, the inequitable treatment of some people as 'normal' and 'rightful' owners of the city, and others as aliens in their own home" (Yeoh \& Lin, 2012, p.212).

In Gaziantep, entrepreneurship has also emerged as a cultural dimension that firmly shapes the collective social consciousness of city dwellers. However, this phenomenon is neither specific to Gaziantep nor unique to the city. On the contrary, a new city model emerged in Europe and America in the 1980s and afterwards in all world cities. Following the 1970s, the decline of the city as a center of manufacturing and the emergence of global economies lead to a crisis in Europe's and America's industrial cities, and a new urban consensus was reached: the reimagining of cities as sites of consumption (Miles, 2010, p.36). According to Harvey (1989, p.13), the development of tourism and "the production and consumption of spectacles [as well as] the promotion of ephemeral events within a given locale" are emphasized as a means of overcoming crisis in urban economies. Thus, with the entrepreneurial city model, the city takes on a new form, with its entrepreneurial and tourismoriented spaces. During this process, urban culture is transformed into an economic item that is commoditized and marketed (Miles, 2010. p.41-42). Harvey (1989, p.13) has warned that cultural and consumption centers as well as tourist areas established to attract visitors solve urban problems in the short-term but are speculative in the long-run. Moreover, the investments and innovations made to make cities attractive can also be imitated quickly by other cities. This situation induces the short-lived nature of these investments as it provokes competition among cities (Harvey, 1989, p. 12).

This paper considers cosmopolitanism in an urban context and as a global identity trait. The following section details the formation of an entrepreneurial city identity and the role of local politicians, municipalities, chambers and businessmen in this formation. The final section contemplates the characteristics of the cosmopolitan and entrepreneurial city genre as well as new forms of inequality which may accompany it.

\footnotetext{
${ }^{1}$ If we consider international experience as an indicator of cosmopolitanism, the number of Turkish citizens travelling abroad can give us a general idea about cosmopolitan orientations in Turkey. According to the Turkish Statistical Institute, 7,444,414 individuals in Turkey travelled abroad in 2013 (TUİK). On the other hand, in European countries, more than half of the population in 2013 made at least one trip abroad to countries such as Finland (60.7\%), the Netherlands (59.2\%), Denmark (58.0\%), Austria (57.4\%), Sweden (55.2 \%), Ireland $(54.9 \%)$, Belgium (53.4\%), Germany $(52.8 \%)$ and Slovenia $(50.2 \%)$, while in Turkey only $10 \%$ of the population travelled abroad (Eurostat). Considering this figure, we can assume that an elite form of cosmopolitanism is encountered only among a small number of Turks.
} 


\section{The discursive formation of Gaziantep as an entrepreneurial city}

Several scholars have articulated that in recent years, a complex, multi-dimensional crisis has occurred within the socio-economic, civil, and political organization of cities in Turkey. This urban crisis, resulting largely because of changes in the nation state, has witnessed hinterlands becoming more meaningful in the organization of economic, political and social life. While cities have become increasingly involved in globally integrated competition, urban economies have altered both forms of inter-urban and international competition (Jessop, 1998, p. 3-4). Since 1990, global economic integration policies have been implemented in Gaziantep. Indeed, mayors, councilors and businessmen in Gaziantep have endeavored to create an entrepreneurial identity for the city. In entrepreneurial cities, the actors who encourage the entrepreneurial cities promote entrepreneurship in their rhetoric, continually describing the cities as essentially entrepreneurial (Jessop \& Sum, 2000, p.2289). In fact, the construction of an entrepreneurial city involves the gathering of different social forces and institutions to collectively support and strengthen entrepreneurship. This collective action includes the following:

the discursive constitution of economic paradigms, identities and modes of calculation that justify claims about an 'imagined community of entrepreneurial interest' and its associated collective project, the nature and competencies of the actors (not necessarily local or locally dependent) who are mobilized behind the entrepreneurial strategy, the interpersonal, organizational and (inter) organizational mechanisms through which such forces are mobilized and given coherence, and the manner in which these mechanisms are embedded in broader social arrangements so that the capacities of the city (or localized social structure) are in some sense collective and thus irreducible to those of individual actors resident or active therein. (Jessop \& Sum, 2000, p.2291)

Prominent businessmen in Gaziantep have persisted in publicly describing the city in the same terms as mentioned above. In these collective discourses, they have attempted to differentiate Gaziantep from other cities in Turkey in terms of its entrepreneurial spirit. In fact, the mayors, city councils, managers and businessmen of Gaziantep function as a coherent collective social force for creating and producing an entrepreneurial city identity.

In this context, the role of local businessmen in incorporating the city into global markets is significant (Bayırbağ, 2010, p.377). Yüksel (2011, p. 377) has emphasized that Gaziantep's local business associations and chambers have established a network of contacts with the European Union as well as transnational corporations. Moreover, the city has been relatively successful in overcoming problems compared to other cities of the region and, in some cases, to the central government. As mentioned above, local businessmen are also active in constructing the city's identity as entrepreneurial. The following statement issued by a prominent Gaziantep businessman and published in a local newspaper illustrates this case:

If we had government investments in Gaziantep, I think we would become workers or civil servants in our state as well as our father [. . . Muslims, Jews, Christians and Armenians have lived together in this city for many years. A culture of reconciliation, love and tolerance, handicrafts, trade and entrepreneurial structure are the results of this. Everyone has learned something from each other. Our fathers have transformed the textile handicraft works of our grandfathers into a small venture and factory production, and we have turned our family investments into holding company investments. We have never been able to benefit from the governmental incentives in any period. However, the final government incentive decision has been fairly prepared compared to others. Our businesses have grown up without subsidies. When we look at the cities which benefit from governmental incentives, we can see clearly that they cannot perform as well as we ourselves have demonstrated. Gaziantep has achieved this success with entrepreneurial spirit. Studies on this matter justify us. It has been revealed that cities which benefit from governmental incentives have less development rates. We have created the Gaziantep Model in industrialization with our entrepreneurial spirit that we believe is in our DNA, in our genes, knowing our power, not with governmental incentive. (Gaziantep27, 2013) 
Similar to the above rhetoric, the mayor of Gaziantep has distinguished the city in terms of its "entrepreneurial spirit" in her statement to a local newspaper. The similarity in the statements given by the prominent businessman and the mayor is striking:

The entrepreneurial spirit of Gaziantep is as old as the history of mankind [. . .] Fairs made in the city today were made in the halls of the Silk Road in the past [. . .] Gaziantep is an example to the whole region and today, the new generations are as successful as the former ones. We consider individuals as the essence of development. I have witnessed this over the past 12 years, and we have seen older brothers who have been through the mill. This city had its own vision before everybody. The city by its own has put forward its visions for 2023 and 2070. Our city has the best economic figures with its confidence and stability. We are growing faster than Turkey. This city comes together by combining its wisdom. Everyone contributes a share. The city grows like this. (Sabah, 2014)

The discursive constitution of local entrepreneurial identity demonstrated in the above two statements has been collectively adopted and presented by local businessmen and politicians. Indeed, the discourse of the entrepreneurial city has been arranged collectively as a project in which the capacities of cities or the local social structure are not reduced to individual actions. This discourse has been formed by the collective power of local trade associations, chambers of commerce, industries, and urban politicians. It is important to note that the prominent businessman cited above is also the head of the chambers of industry in the city. Referring to the role of mayors and politicians in the implementation of entrepreneurship strategies in different cities around the world, for example in American cities, Hong Kong, and London, Jessop and Sum (2000, p. 2291) have emphasized the need to consider the wide range of actors mobilized for a collective project.

Initiated by the election of a new mayor in Gaziantep in 1989, a new economic consensus in local politics has emerged involving entrepreneurial strategies for penetrating neoliberal policies on transnational capital flows into locality (Yüksel, 2011, p. 377). While an entrepreneurial discourse has been adopted and the ideals of the city accordingly reimagined, cultural and historical areas in the city have been commoditized as is the case with other entrepreneurial cities.

The following section of this paper will focus on how the old city center and urban culture in Gaziantep have been commoditized and how a cosmopolitan urban identity has been established.

\section{The city and cosmopolitan cultural genre}

In recent studies on cities in Turkey, it has been noted that the local cultures have transformed into marketable commodities. Öncü (2007) has cited a theme park in Istanbul known as Miniatürk as an example of the use of cultural heritage as a marketable commodity. In Gaziantep, cosmopolitanism has become a feature of urban imagery. The reimaging of the city as cosmopolitan has been accompanied by the commodification of city space and culture. In recent years, the city of Gaziantep - which previously boasted only an archaeological museum - has become part of this process. The reconstruction of Gaziantep's identity as cosmopolitan has necessitated the transformation of the city's historical past into a consumption item. Currently, the city is being promoted in the tourism industry based on its new identity and urban spaces.

The phrase "marketing of cities," which has been characterized as a self-conscious method of obtaining economic objectives, was first used in Europe in the 1980s. It refers to the contemporary phenomenon of producing spaces and cultures in cities for the purpose of consumption. When marketing a city, it is desirable to achieve two goals: positioning geographically flexible economic ventures in a specific location and strengthening tourism (Miles, 2010, p.40-42). Regarding tourism, Hannerz has described it as an essential characteristic of world cities. He has asserted that world cities with a global character possess 
the following groups of actors; transnational businessmen, a Third-World population, cultural producers, and tourists (1996: 129-131). Concerning urban tourism, urban culture functions as an economic resource. The history of the city is reestablished as a source of pride for the past and is manipulated for economic gain. Moreover, the local population are convinced that they are an important part of this process and that good things are done for their cities in their name (Miles, 2010, p.40-42). It has been argued that entrepreneurial cities invest in both high and low cultural capital forms in order to strengthen local tourism. Museums and galleries, historical buildings, modern venues, restaurants, and clubs are all investments meant to attract tourists to the cities. Ward refers to an urban image containing new consumption spaces in the city center or the old industrial center as an "anime" city image (Ward ctd. in Miles, 2010, p.39).

Though the manufacturing sector functions as the main economic driver of Gaziantep, local initiatives have further supported the city's tourism economy in recent years. The mayor of Gaziantep has expressed her strategy of promoting local culture with the slogan, "From local to universal and from tradition to future." Moreover, following a study conducted four years ago to measure Gaziantep's competitiveness, it was determined that the city was strong in terms of its archaeological heritage and cuisine (Milliyet, 2017). Thus, the mayor has emphasized these features in order to increase tourism. The local government has been working to strengthen the gastronomic and archaeological infrastructure of the city and market these features both nationally and internationally. As a result, the city was recently included in the category of gastronomy of UNESCO's Creative Cities Network. In addition, Gaziantep's historical city center has undergone numerous changes since its decline until its recent "rebirth." Extensive restoration efforts have transformed abandoned and dilapidated buildings in the old city center into a series of museums, markets, souvenir shops, and boutique hotels. Moreover, old houses near the city's castle have been either restored for presentation to tourists or transformed into museums featuring local foods, glass, toys, and history. Currently, there are more than ten museums in Gaziantep ${ }^{2}$. The mayor has promoted the city's cosmopolitanism and multicultural identity in the following way:

All civilizations in this geography, which is as old as human history, are the greatest treasure of our cultural heritage in all the periods that have come to this day. We would like to promote this treasure, this pearl, and diamond to the world. In this regard, our greatest power is qualified human power. (Doğru Haber, 2017)

For Huyssen (2000, p.24), the development of museum villages and the restoration of old urban centers should be considered in relation to the "globalization of memory." According to him, the early decades of the twentieth century were characterized by a focus on "present futures" (2000, p.21). However, by the 1980s, the focus shifted from "present futures" to "present pasts." Western societies no longer privileged the future but shifted their concern to memory of the past. Restoration efforts in Gaziantep's old city center indicate that there is now more interest in the past rather than the future of the city. Signifiers of local, national, and traditional identity as well as cosmopolitan identity can be found in the old city center today. A newly renovated building that has been transformed into a hotel-one of the oldest Ottoman inns in the city with its black outdoor window shades - can be distinguished from neighboring old-fashioned buildings in its simultaneous invocation of the past and present. You might compare this phenomenon with the effect of old-fashioned yet newly constructed cobblestones in the streets of several cosmopolitan cities globally. Aiello

\footnotetext{
${ }^{2}$ The museums recently constructed are: Zeugma Mozaik Müzesi, Bayazhan Gaziantep Kent Müzesi, Gaziantep Arkeoloji Müzesi, Gaziantep Atatürk Anı Müzesi, Gaziantep Kültür ve Tarih Müzesi, Gaziantep Oyuncak Müzesi, Yesemek Açık Hava Müzesi, Gaziantep Savaş Müzesi, Hasan Süzer Etnoğrafya Müzesi, Emine Göğüş Gaziantep Mutfak Müzesi, Ömer Ersoy Kültür Merkezi ve Medusa Cam Eserler Müzesi ( Gaziantep İl Kültür ve Turizm Müdürlüğü)
} 
describes this artistic choice as a "deliberate act of stylistic referencing" signifying two things: historical and local identity on the one hand and cosmopolitanism on the other" (2011, p.356).

While spaces in the old city are reestablished with a new cosmopolitan identity, this identity is shaped by the elite classes of the city. Many studies have identified how so-called cosmopolitan strategies have produced class politics and how urban elites have played a role in the formation of urban cultures (Miles, 2010, p.42; Young, Diep \& Drabble, 2006, p.1689). In Gaziantep, while the urban space has been marketed as cosmopolitan, the city culture and its past have been rewritten through the city elites. One such example in Gaziantep has involved the renovation of a house in the old city quarter, where Ottoman minority groups used to live. Today, the building has been converted into a food museum named after one of the established families of the city. In an effort to create a marketable urban culture, the city's cuisine has been promoted via the name of a local elite family.

Alongside this historical revision that erases the memory of actual individuals and events in favor of the elite, the cosmopolitan and entrepreneurial city may also erase any outliers that do not fit within its image. According to Young, Diep \& Drabble, it must be questioned whether the production of a cosmopolitan space is linked to a paradoxical displacement of other forms of "disruptive" difference which need to be excluded from certain spaces (2006, p. 1689). At the same time, however, certain forms of difference may be valued. A good example of this kind of exclusion of certain forms of difference can be observed in Gaziantep's old city quarter. Prior to renovation and reconversion, the quarter was considered by many as an unsafe city district. Most of the buildings were locked and dilapidated and/or vandalized. Now the quarter is well lit and surveilled, thus regarded by many to be considerably safer. Consequently, the quarter has been symbolically and materially separated from the surrounding neighborhoods in terms of its physical and aesthetic appearance. Aiello has described urban renewal in Bologna's Manifattura delle Arti as a contemporary strategy of global(ist) communication and an interruption with the surrounding neighborhood that "further reinforces some of the very same spatial and social divisions that predated the area's reconversion, while also creating new insidious forms of separation and inequality" (2011, p.349). The renovation of Gaziantep's old city quarter similarly has interrupted the flow of the neighborhood. The area surrounding the quarter contains a shopping mall for the middle class. Consequently, locals including those of the upper class have abandoned the quarter itself, which once served as the only shopping center of the city. Alongside reconversion, the old city quarter has become separated from the everyday lives of the surrounding neighborhoods and organic community life. Now, it is visited mostly by tourists and city dwellers.

In Gaziantep, cosmopolitanism has become a feature of urban imagery. The reimagining of the city as cosmopolitan has also been accompanied by the commodification of city space and culture, the erasure of historical outliers, and the exclusion of certain groups of individuals. This raises the question of whether the production of the cosmopolitan city contributes to the deepening of social exclusion and distinction.

\section{Conclusion}

As mentioned previously, a new city model emerged in Europe and America in 1980 - that of the cosmopolitan and entrepreneurial city. By means of urban renewal, which has become a globalized genre of cultural production, cities have been redesigned according to this model. Accordingly, these cities have transformed their identities into marketable commodities in both local and international markets. In recent years, Gaziantep's city identity has been re-established as cosmopolitan and entrepreneurial. This paper focused on the 
production and consumption of Gaziantep as an entrepreneur and cosmopolitan city. While local municipalities and businessmen have promoted an entrepreneurial and cosmopolitan identity for the city, historical sites have been transformed into popular tourist attractions and local heritage is being rediscovered.

This study also focused on the production of cosmopolitan culture in Gaziantep. In particular, the marketing of the old city quarter has aided in this production, as it has increased local tourism. On the other hand, this re-imagining has disrupted organic community life. Moreover, the case study of Gaziantep has demonstrated that the notion of a cosmopolitan city relies upon the reproduction of deepening inequalities and erasure of local identity. For example, new facilities with cosmopolitan signifiers turn away the local community as they become tourist hubs. Although the concept of cosmopolitanism implies the acceptance of differences, the cosmopolitan reconstruction of Gaziantep has prioritized the elite class. This is an aesthetic that defines some class cultures as "acceptable" or "unacceptable." In summary, this study has indicated the necessity of further research on cosmopolitan city spaces and the cosmopolitan cultural production of the cities.

\section{References}

Aiello, G. (2011). From wound to enclave: The visual-material performance of urban renewal in Bologna's manifaturra delle Arti. Western Journal of Communication, 75(4), 341366. doi: 10.1080/10570314.2011.586971

Akşit, B., Akçay, A. (1999). "GAP: Bir kırsal dönüşüm projesi ve tarımsal sulama.” A. Hacımirzaoğlu (Ed.), 75.Yılda köylerden şehirlere (pp.323-332). İstanbul: Tarih Vakfı Yayınları.

Bayıbağ, M. K. (2010). Local entrepreneurialism and state rescaling in Turkey. Urban Studies, 47 (2), 363-385. doi:10.1177/0042098009349022.

Canbakal, H. (2009). 17.yuzyilda Ayintab: Osmanli kentinde toplum ve siyaset. Istanbul: Iletisim.

Coulangeon, P. (2017). Cultural openness as an emerging form of cultural capital in contemporary France. Cultural Sociology, 11(2), 145-164. doi: $10.1177 / 1749975516680518$

Devlet İstatistik Enstitüsü (2002). Nüfus istatistikleri. Ankara: Devlet İstatistik Enstitüsü Matbaasi.

Doğru Haber Gazetesi, (23.03.2017). Turizm ve seyahat acentalart Gaziantep'te bir araya geldi. Date of Access: 12.03.18. https://dogruhaber.com.tr/haber/241799-turizm-veseyahat-acentalari-gaziantepte-bir-araya-geldi/.

Eurostat Date of Access:12.03.18. http://ec.europa.eu/eurostat/statisticsexplained/index.php/Tourism_statistics_-_participation_in_tourism.

Gaziantep 27 Gazetesi, (17 Aralık 2013). Girişimci kimlik kazandlk. Date of Access: 12.03.18. http://www.gaziantep27.net/m/index.php?islem=detay\&id=470769

Gaziantep İl Kültür ve Turizm Müdürülüğü. Date of Access: 12.03.18. http://www.gaziantepturizm.gov.tr/TR,131846/muzeler.html

Göç İdaresi Directorate General of Migration Management): Date of Access: 31.04.18. http://www.goc.gov.tr/icerik3/gecici-koruma_363_378_4713

Hannerz, U.(1996). Transnational connections: Culture, people, places. Florence, KY, USA: Routledge.

Huyssen, A.(2000). Present pasts: Media, politics, amnesia. Public Culture, 12 (1): 21-38.doi: 10.1215/08992363-12-1-21.

Jessop, B. (1998). The enterprise of narrative and the narrative of enterprise: place marketing and the entrepreneurial city, in T. Hall and P. Hubbard (Eds.), The entrepreneurial city (pp.77-99). Chichester: Wiley. 
Jessop, B. and Sum, L. N. (2000). An entrepreneurial city in action: Hong Kong's emerging strategies in and for (inter)urban competition. Urban Studies, 37 (12): 2287- 2313. doi: 10.1080/0042098002 0002814

Karademir, Hazir, I. (2014). Boundaries of middle-class identities in Turkey. The Sociological Review, 62 (4):675-697. doi: 10.1111/1467-954X.12114

Harvey, D. (1989). From managerialism to entrepreneurialism: The transformation in urban governance in late capitalism. Geografiska Annaler, 71 (1): 3-17. doi: $10.2307 / 490503$

Lamont, M. And Aksartova, S. (2002). Ordinary cosmopolitanisms; Strategies for bridging racial boundaries among working-class men. Theory, Culture and Society, 19 (4): 125. doi: 10.1177/0263276402019004001

Miles, S. (2010). Spaces for consumption, India: Sage.

Milliyet Gazetesi, (03.10.2017). Yerel yönetimler ve turizm komisyonu Fatma Şahin başkanlı̆̆ında toplandl, Date of Access: 12.03.18. http://www.milliyet.com.tr/yerelyonetimler-ve-turizm-komisyonu-gaziantep-yerelhaber-2313942/.

Öncü, A. (2007). The politics of Istanbul's Ottoman heritage in the era of globalism: Refractions through the prism of a theme park. B. Drieskens, F. Mermier, and H. Wimmen, (Eds.), Cities of the South: Citizenship and exclusion in the 21st Century (pp.233-264). London, Beirut: Saqi Books.

Rankin, B., Ergin, M., and Gökșen, F. (2013). A cultural map of Turkey. Cultural Sociology, 8 (2): 159-179. doi:10.1177/1749975513494878.

Sabah Gazetesi,(28.10.2014). Başkan Fatma Şahin: Gaziantep yeniliğe açık, Date of Access: 12.03.18. http://www.sabah.com.tr/guney/2014/10/28/baskan-fatma-sahin-gaziantepyenilige-acik? paging $=1$.

Skribis, Z. and Woodward, I. (2007). The ambivalence of ordinary cosmopolitanism: Investigating the limits of cosmopolitan openness. The Sociological Review, 55 (4):730-747. Doi: 10.1111/j.1467-954X.2007.00750.x

TÜİK. Turkish Statistical Institute (2007). Bölgesel göstergeler. Türkiye İstatistik Kurumu Matbaasi: Ankara.

TÜİK. Turkish Statistical Institute (2011). Bölgesel göstergeler, TRC1 Gaziantep, Adıyman, Kilis 2010. Türkiye İstatistik Kurumu Matbaası: Ankara.

TÜIK Turkish Statistical Institute. Date of Access: 12.03.18. http://www.tuik.gov.tr/jsp/duyuru/upload/yayinrapor/Vatandas_Giris_Anketi_Raporu_ 2013.pdf.

TÜIKK Turkish Statistical Institute. Yıllara Göre Il Nüfusları Date of Access: 18.05.2018 http://www.tuik.gov.tr/UstMenu.do?metod=temelist.

Yeoh, B. and Lin, W. (2012). Cosmopolitanism in cities and beyond. G. Delanty (Ed.), Routhledge handbook of cosmopolitan studies (pp.208-220). London:Routhledge.

Young, C., Diep, M. and Drabble, S. (2006). Living with difference? The 'cosmopolitan city' and urban reimaging in Manchester, UK. Urban Studies, 43 (10): 1687-1714. doi: $10.1080=00420980600888486$

Yüksel, A. S. (2011). Bir şehir efsanesi, göç ve değişen Antep. M. N. Gültekin (Ed.), Ta ezelden taşkındır ... (pp.371-392). İstanbul:İletişim.

Yüksel, A., S. (2013). Localization of neoliberalism, space, culture and materiality in Southeast Turkey (Unpublished PhD Thesis).Central European University Department of Sociology and Social Anthropology, Hungary. 